\title{
LATIN-AMERICAN WRITING INITIATIVES IN ENGINEERING FROM SPANISH-SPEAKING COUNTRIES
}

\author{
Elizabeth Narváez-Cardona* \\ Universidad Autónoma de Occidente \\ Cali, CO
}

\begin{abstract}
This article analyzes Latin-American publications from Spanish-speaking countries to map programs pursued in the region and then provide a context to envision further research agendas for Latin-American Writing Studies in Engineering. The analysis of 22 publications suggests that initiatives and studies in Engineering are recent (as of 2009). The sample reveals an emphasis on pedagogically-oriented publications focused on Engineering as one field. The trends suggest that the Latin-American writing advocates in Engineering might broaden research scopes by incorporating theoretical frameworks for a) exploring and understanding different roles of writing across time and curriculum in student learning and by Engineering subfields and, b) exploring theoretical approaches to understand genres beyond individual texts (genre repertoires and genre systems).
\end{abstract}

Keywords: Engineering Writing Initiatives in Latin America; Engineering Writing; Technical Communication

\section{Introduction}

In Latin America there is no field known as writing studies and there is a lack of systematic research to document the history and the emergence of the field (Navarro et al., 2016). However, studies and pedagogic initiatives on reading and writing in higher education date back to 2000. An interregional project titled "Initiatives of Reading and Writing in Higher Education in Latin America (ILEES)" conducted between 2013-2015 aimed at mapping endeavors in Argentina, Chile, Colombia, Mexico, Puerto Rico, and Venezuela ${ }^{1}$. ILEES data show that Latin American writing advocates are affiliated to diverse disciplinary fields: Language Sciences, Applied Linguistics, Systemic Functional Linguistics, Education, Psychology, and
Humanities. Furthermore, there are no central venues in the region, journals or associations, on professional or disciplinary writing; thus, academic publications primarily circulate in journals affiliated to Linguistics and Language Sciences. ${ }^{2}$ The ILEES project also reveals that the most frequent initiative across countries is courses on freshman composition in Spanish, although writing centers and programs are rapidly emerging in the region (Narváez, 2014). The analysis of information available on the websites of writing centers and programs reveals that despite an advocacy for supporting disciplinary writing endeavors, online materials (guidelines, activities, forums) portray academic writing as a general skill in freshman years regardless of disciplines, since writing support is focused on essays, book reviews, literature reviews and

\footnotetext{
* Professor at the Language Department at Universidad Autónoma de Occidente, in Colombia. She completed her PhD in Education at University of California Santa Barbara (UCSB) with an emphasis in Teaching and Learning and Writing. She is interested in academic writing, and in understanding the scholastic differences between the United States and Latin America in terms of public educational policies, institutional identities, historical accounts, and local resources. Her email address is enarvaez@uao.edu.co
} 
a general genre named "writing assignments" (Narváez, 2015). Therefore, in Latin America there is no specific field of writing in the disciplines (WID), in general, or Technical Communication, in particular.

The interdisciplinary field of Technical Communication has developed in the U.S. as part of historical and evolutionary interactions among economic changes, scientific developments, and digital technology innovations. The field has been fostered especially by advancement of engineering and related disciplines which generate both scientific knowledge and financial profit. This interdisciplinary field has emerged to research and teach communication practices within institutions (companies, research centers, civil organizations, government, and universities) associated with scientific and technological changes and corporate capitalism in North America.

In Latin American countries, global trends of science, innovation, and technology transfer appear as part of higher education reforms and funding research agendas. Regardless of the gap in progress and the presence of diverse needs among regions and economies, Latin-American faculty and students in Engineering are asked to produce cutting-edge knowledge and artifacts within a fierce competition. Consequently, contributions of technical communication programs are valuable across regions, especially in Spanish Latin America, provided they are developed to help stakeholders by taking critically into account their local conditions and challenges of global and transcultural demands.

Given the emerging Latin-American body of initiatives and studies in Engineering writing, this article aims at exploring features of these specific endeavors reported by publications. Journal articles and oral communications have been explored to provide tentative answers for the following research questions:

a. When and where have studies and interventions on Engineering writing started?

b. What are the reasons justifying the emergence of studies and interventions related to Engineering writing? c. What theories of genre have framed the studies and initiatives?

d. What Engineering fields have been of interest?

e. To what extent have initiatives and studies been institutionalized and interdisciplinary?

f. What type of language is studied or taught (linguistic systems; mathematical and linguistic systems, and multimodal systems)?

g. Are computers part of the studies and interventions on Engineering writing?

h. What curriculum and learning moments have been of interest?

i. What agendas are currently proposed on Engineering writing?

This article takes into account the important call for conducting research about writing and communication across cultures avoiding an ethnocentric bias (Thatcher, 1999; 2000, 2001, 2005, 2009, 2010). To do so, the aforementioned questions are, in the first place, answered by describing the sample and the results of the analysis of Latin-American publications on Engineering writing. Since the ultimate goal of this study is to provide a context to boost agendas for LatinAmerican Writing Studies in Engineering and the development of Technical Communication Programs in the region, ${ }^{3}$ a section framing technical communication programs in the U.S. is presented and utilized, in the discussion section, to identify shared features and differences between the Latin-American endeavors and the U.S. programs. This contrast is useful to envision Latin-American research agendas by valuing what has been locally developed and identifying international debates in which Latin-American writing advocates can contribute in the field of Technical Communication. 


\section{A qualitative analysis of publications that report Latin-American writing initiatives in Engineering}

Since there are no central venues (either journals, professional associations, or open-access projects) to easily access the literature on writing studies in Latin America, in general, and Engineering writing, in particular, the sample in appendix 1 was comprised of 22 publications (journal articles and oral communications) collected as a convenience sampling. I revised the published memoirs in $\mathrm{CD}$ of two academic events ${ }^{4}$ I participated in August 2014 by electronically searching across the files with the label "Engineering". During the same period, I emailed Latin-American colleagues I knew they worked on Engineering writing and asked for their publications. By using this data gathering, I collected 16 publications. In December 2014, the first Latin-American Data Base on reading and writing studies was launched (Cisneros, 2014), ${ }^{5}$ and I also searched by using the tag "Engineering"; 6 other publications were gathered.

Titles, abstracts, and sections of conclusions and discussion of the publications were read to conduct the analysis. Table 1 presents the relationship between the research questions and the analytical categories utilized:

Table 1

Relationship between the research questions and the analytical categories

\begin{tabular}{|c|c|}
\hline Research questions & Analytical categories \\
\hline $\begin{array}{l}\text { 1. When and where have studies and interventions on } \\
\text { Engineering writing started? }\end{array}$ & Years and countries of the publications \\
\hline $\begin{array}{l}\text { 2. What are the reasons justifying the emergence of } \\
\text { studies and interventions related to Engineering writing? }\end{array}$ & $\begin{array}{l}\text { Emphasis of the publications (pedagogically-oriented, } \\
\text { research-oriented, or research on pedagogical } \\
\text { experiences). } \\
\text { Reasons for studying or leading the initiatives: The } \\
\text { following grounded sub-categories were created from the } \\
\text { data: } \\
\text { - Writing to learn } \\
\text { - Writing for scientific practices } \\
\text { - Writing for professional practices } \\
\text { - Writing for Writing Research } \\
\text { - Senior thesis writing } \\
\text { - Reading for learning }\end{array}$ \\
\hline $\begin{array}{l}\text { 3. What theories of genre have framed the studies and } \\
\text { initiatives? }\end{array}$ & $\begin{array}{l}\text { What might count as "genre": There is a methodological } \\
\text { debate in the field of Genre Studies about theoretical and } \\
\text { methodological limitations in describing and labeling } \\
\text { genres (Devitt, Bawarshi and Reiff, 2003; Herrington } \\
\text { \& Moran, 2005; Gardner \& Nesi, 2012); therefore, the } \\
\text { following categories were defined in advance to analyze } \\
\text { the notion of "genre" as a theoretical entity based on the } \\
\text { overview presented by Bawarshi and Reiff (2003): } \\
\text { - An individual textual-linguistic entity. } \\
\text { - As a group of linguistic, textual, and/or rhetorical } \\
\text { patterns of language use that has been called "genre } \\
\text { families" or "genre repertoires". } \\
\text { - As a language usage and circulation enacted by different } \\
\text { participants/roles within discourse communities and } \\
\text { actual institutions (genre systems). }\end{array}$ \\
\hline 4. What Engineering fields have been of interest? & Mentions of Engineering fields, if any \\
\hline
\end{tabular}




\begin{tabular}{|c|c|}
\hline $\begin{array}{l}\text { 5. To what extent have initiatives and studies been } \\
\text { institutionalized and interdisciplinary? }\end{array}$ & $\begin{array}{l}\text { Grounded categories were created from the data based on } \\
\text { mentions of interdisciplinarity (efforts between writing } \\
\text { instructors and disciplinary-professors or practitioners), } \\
\text { and degree of institutionalization (If initiatives have had } \\
\text { departmental supports and, have been part of curriculum } \\
\text { reforms or products of faculty development programs) }\end{array}$ \\
\hline 6. What type of language is studied or taught? & $\begin{array}{l}\text { Categories were defined in advance: } \\
\text { - linguistic systems } \\
\text { - mathematical and linguistic systems } \\
\text { - multimodal systems }\end{array}$ \\
\hline $\begin{array}{l}\text { 7. Are computers part of the studies and interventions on } \\
\text { Engineering writing? }\end{array}$ & Mentions of computers, if any \\
\hline $\begin{array}{l}\text { 8. What curriculum and learning moments have been of } \\
\text { interest? }\end{array}$ & $\begin{array}{l}\text { For pedagogically-oriented publications, the analysis } \\
\text { aimed at identifying curriculum learning moments with } \\
\text { the following categories defined in advance: } \\
\text { a) for undergraduate and graduate programs: } \\
\text { - Freshman } \\
\text { - Sophomore } \\
\text { - Junior } \\
\text { - Senior } \\
\text { - Across several college terms (Writing across the } \\
\text { curriculum) } \\
\text { b) after/outside of curriculum experiences (practitioners/ } \\
\text { professionals). }\end{array}$ \\
\hline $\begin{array}{l}\text { 9. What agendas are currently proposed on Engineering } \\
\text { writing? }\end{array}$ & $\begin{array}{l}\text { The analysis of topics reported as conclusions, limitations, } \\
\text { and implications in the publications was also conducted } \\
\text { to identify agendas stated by the author(s). The sections } \\
\text { of conclusions and discussion were read to infer the main } \\
\text { claims. }\end{array}$ \\
\hline
\end{tabular}

Given the size (22 publications), and type of the sample (convenience sampling), the analysis of the prior categories was done by counting occurrences when identifiable, and the results are only descriptive.

\section{Results}

1. When and where have studies and interventions on Engineering writing started?

The initiatives/studies on Engineering writing appear to be recent in Latin America. The oldest paper of the sample was published in 2009. However, after 2010 there was a growth in the number of publications according to the data behavior in previous years (figure 1).
Figure 1

Occurrences of the publications by year

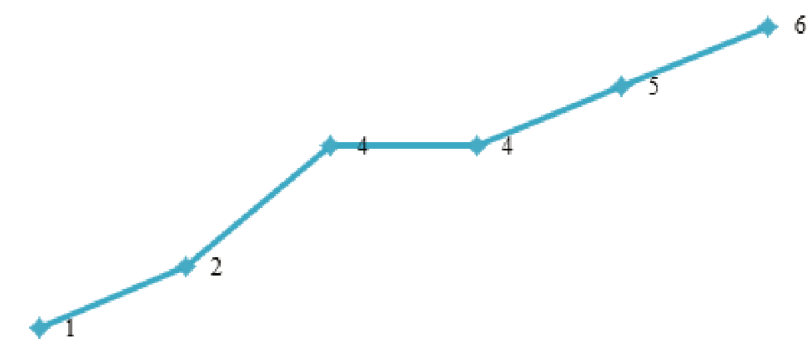

$\begin{array}{llllll}\text { Year } 2009 & \text { Year 2010 } & \text { Year 2012 } & \text { Year 2013 } & \text { Year 2014 } & \text { Y ear 2015 }\end{array}$

The analysis of the sample suggests that Argentina, Colombia, and Chile are the leading countries of the initiatives/studies that are published either as journal articles or oral communications. However, Argentina 
might be the country in which more publications have been produced (11 cases) (figure 2).

\section{Figure 2}

Occurrences of the publications by country

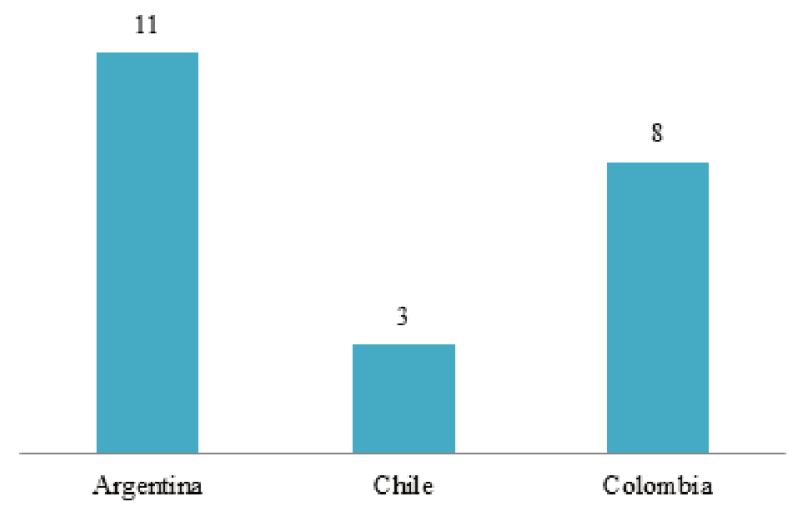

2. What are the reasons justifying the emergence of studies and interventions related to Engineering writing?

The publications were primarily pedagogicallyoriented by reporting either experiences or research on pedagogical experiences (14 cases), in contrast to papers that were research-oriented but not related to pedagogical experiences ( 8 cases). The following is an example of a Colombian pedagogically-oriented publication in which writing is used to support student learning in a class of electronic Engineering ${ }^{6}$ :

\section{Example 1}

Article title: "Integration of reading and writing in the laboratory course of electronic devices in Electronic Engineering" (2014)

This paper presents a model integrating reading and production of scientific texts as tools to build disciplinary knowledge. In doing so, the goal is to develop critical and analytical thinking, and communication skills of students enrolled in the course "Laboratory of electronic devices", one of the core experimental courses of the major in Electronic Engineering program at the University del Valle.
An example of a research-oriented publication is as follows; a study is conducted to explore academic and professional genres required during undergraduate education in Industrial Engineering in a public Argentine university:

\section{Example 2}

Article title: "Genres and Engineering education: from university to the industry" (2015)

This article reports the results of the first stage of a research on academic and professional genres required during undergraduate education in Industrial Engineering in a public Argentine university. This study includes three sites to study genres: faculty members and students, as participants, and texts, as products. This paper reports faculty members' perspective collected by interviews to explore what genres are required in the academic training of industrial engineers, and analyzes how these genres are distributed throughout the program $(\ldots)^{7}$

The research oriented publications were journal articles, whereas the publications pedagogicallyoriented, including those that are research on pedagogical experiences, were both journal articles and oral communications.

The analysis of reasons for studying or leading initiatives on Engineering writing also suggests that the initiatives/studies have been primarily focused on incorporating writing to learn ( 11 cases in figure 3 ). The following case illustrates this tendency by presenting a fragment of a Colombian pedagogically-oriented publication in which writing assignments were the core of a pedagogic intervention in a course of Computer Engineering:

\section{Example 3}

Article title: "Writing as a means of learning and communication in the Engineering Software Processes course. Collaborative work between language teachers and those of other disciplines" (2014) 
This paper aims to analyze on writing guidance and assessment offered in a course titled "Software Engineering Processes" and its impact in students for learning content knowledge. The research relies on theoretical frameworks on Academic Literacy and Writing across the Curriculum. Writing assignments were designed collaboratively between the instructor of the course and a writing instructor. A case study was conducted based on this experience (...) The results show as influential elements in the learning process: instructors' guidelines, evaluation rubrics, instructor's feedback, student-teacher conferences, assigning writing tasks with specific purposes, as well as opportunities to write drafts and present progress reports (...)

\section{Figure 3}

Reasons for studying or leading initiatives on Engineering writing

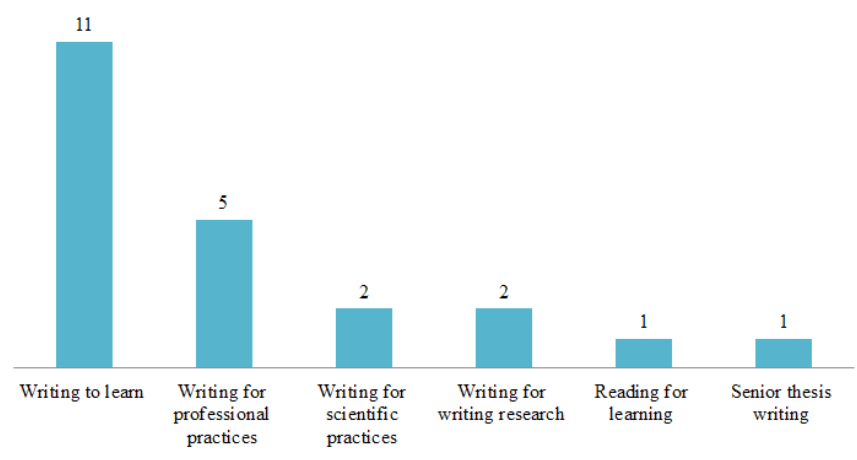

3. What theories of genre have framed the studies and initiatives?

The trend of the initiatives and studies being primarily focused on incorporating writing to learn might be also related to 14 of the 22 articles in the sample thematizing genres as textual- linguistic entities. Out of 14 cases, 4 publications are research-oriented, 6 are pedagogically-oriented, and 4 are research on pedagogical experiences. The following fragment illustrates these cases by presenting an excerpt of an Argentine study about a pedagogic intervention focused on a professional Engineering genre named "the yearly memory":

\section{Example 4}

Article title: "Professional genres in the engineer learning process" (2013)

\section{Introduction}

(...) In this research, we present a didactic design that articulates research work about professional genres and disciplinary contents based on teaching a professional genre. More specifically, it is about an experience that took place in an Economics course for Engineers in which the specific teaching of a professional genre, the yearly memory, is addressed in relation with other contents of the course program (...)

The tendency on writing to learn approach throughout the publications might be connected with some of the types of genres mentioned in the sample (i.e., writing assignments, summaries, and computinglaboratory tasks) (table 2).

Table 2

Occurrences of individual genres mentioned in the publications

\begin{tabular}{|l|l|}
\hline Individual genres & Occurrences \\
\hline Writing assignments & 3 \\
\hline Computing laboratory tasks & 2 \\
\hline Summaries & 2 \\
\hline Annual report & 1 \\
\hline Lab reports & 1 \\
\hline $\begin{array}{l}\text { Reports of formative research } \\
\text { experiences }\end{array}$ & 1 \\
\hline Mathematical texts & 1 \\
\hline Pedagogic journal & 1 \\
\hline Research report & 1 \\
\hline Standardized operating procedure & 1 \\
\hline Textbooks & 1 \\
\hline $\begin{array}{l}\text { Weekly reports for solving problems } \\
\text { with theoretical justifications }\end{array}$ & 1 \\
\hline
\end{tabular}

4. What Engineering fields have been of interest? 
The initiatives/studies address primarily "Engineering" as one field (10 cases), while less common are the initiatives/studies bounded by Engineering subfields (figure 4).

\section{Figure 4}

Engineering fields mentioned by the studies/initiatives

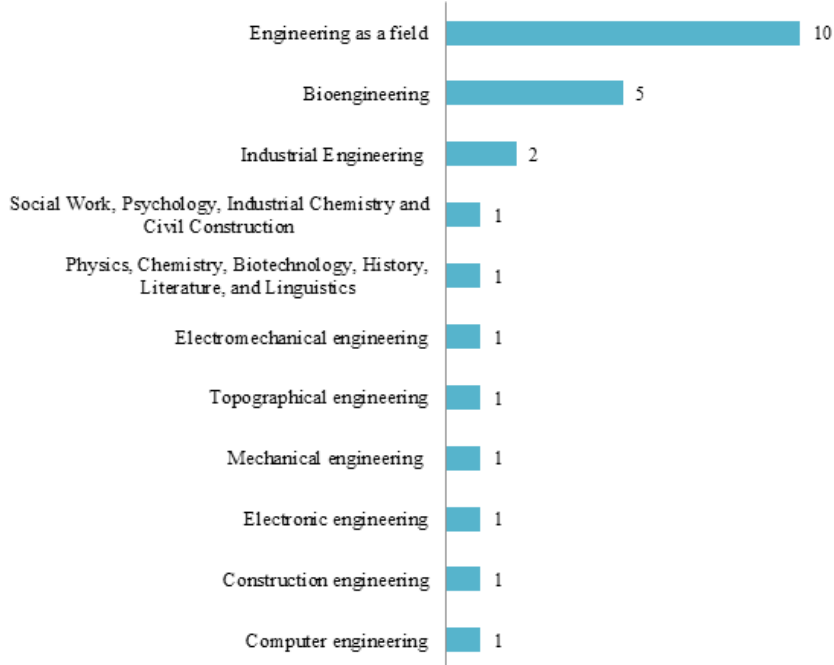

5. To what extent have initiatives and studies been institutionalized and interdisciplinary?

Regarding institutionalization and interdisciplinarity, the sample suggests that the studies/ initiatives have been conducted as interdisciplinary efforts between writing instructors and disciplinaryprofessors or practitioners (16 cases out of 22). The following fragment illustrates this tendency by reporting a Colombian initiative of an interdisciplinary team teaching between a writing instructor and an Engineering instructor for a class in Materials Resistance:

\section{Example 5}

Article title: "Summaries as a learning strategy" (2012)

\section{Summary}

This article presents the findings of an interdisciplinary study on summary writing as a learning strategy which was carried out by a language professor and an Engineering professor in the Materials Resistance course, offered to Universidad [name of the university]
Engineering students. The ultimate purpose in using this strategy was to raise students' consciousness about the key role of writing in their learning process. Unlike traditional summary writing, these ones were not written for the professor for him to assess whether the students had reviewed course contents. Instead, summaries provided the students with an opportunity to monitor their own learning process and express what they had learned in a written format (...)

At least 13 cases of the studies/initiatives reported have implied certain degree of institutionalization (i.e., they have had departmental supports and have been part of curriculum reforms or products of faculty development programs). This tendency is illustrated by the next example about a research project conducted as part of an Argentine institutional program for teaching academic and professional literacy across curriculum:

\section{Example 6}

Article title: "Professional literacy during the university career: between the university and the enterprise" (2015)

\begin{abstract}
(...)This paper presents some partial results of an ongoing research project about writing practices in the Industrial Engineering field. As part of the activities of an institutional program for teaching academic and professional literacy across the university curriculum (PRODEAC) developed at Universidad Nacional de General Sarmiento (UNGS), we surveyed a group of engineers in order to analyze the genres employed in professional settings (...)
\end{abstract}

6. What type of language is studied or taught?

In 16 cases in the sample, it was not possible to identify the type of language addressed/studied in the initiatives/studies of the publications; however, the cases analyzed suggest that there is an attempt to address linguistic and mathematical systems by articulating them (4 cases), as well as see language as 
multimodal (1 case). The following case illustrates with a research project that aimed at describing and quantifying multisemiotic artifacts emerging from a Chilean corpus collected in twelve $\mathrm{PhD}$ programs:

\section{Example 7}

Article title: "Multisemiosis and corpus linguistics: multisemiotic artifacts in the texts of six disciplines in the academic pucv-2010 corpus" (2010)

\begin{abstract}
From strictly linguistic studies, the characterization of multisemiotic written specialized texts has been scarce or almost null. Not many corpus-based studies focus on the description of graphs, tables, and diagrams, as well as their layouts, as part of academic texts. The objective of this study is to identify, describe and quantify the occurrence of (multi)semiotic artifacts which are present in a sample of texts (1.043) belonging to the PUCV-2010 Academic Corpus. The corpus was collected in twelve $P h D$ programs in six Chilean universities and comprises all the documents students are given to read during their formal curricula, with the exception of those included in the final doctoral research $(3,160$ written texts, which are distributed among Physics, Chemistry, Biotechnology, History, Literature, and Linguistics) (...)
\end{abstract}

7. Are computers part of the studies and interventions on Engineering writing?

Computers were mentioned as part of the initiatives/studies in 3 cases (reported as part of the same pedagogical experience). The case below shows these types of mentions in an Argentine action-research experience in which students were asked to perform computer assignments in a calculus course:

\section{Example 8}

Article title: "Early error detection: an action-research experience teaching vector calculus" (2013)
This paper describes an action-research experience carried out with second year students at the School of Engineering of the National University of Entre Ríos, Argentina. Vector calculus students played an active role in their own learning process. They were required to present weekly reports, in both oral and written forms, on the topics studied, instead of merely sitting and watching as the teacher solved problems on the blackboard. The students were also asked to perform computer assignments, and their learning process was continuously monitored (...)

8. What curriculum and learning moments have been of interest?

Theinitiatives/studieshavebeenfocusedondifferent learning moments (when identifiable): undergraduate freshman years and across the undergraduate curriculum (3 cases each); undergraduate sophomore and junior years (2 cases each); and, undergraduate senior and practitioners ( 1 case each) (table 3 ) (out of 12 cases that mention learning moments associated with initiatives or studies, 4 publications are researchoriented, 6 are pedagogically-oriented, and 2 are research on pedagogical experiences).

Table 3

Occurrences of learning moments in which writing is incorporated by the initiatives pedagogically-oriented or genres that are studied in different learning moments

\begin{tabular}{|l|l|}
\hline Learning moment & Occurrences \\
\hline Undergraduate senior (US) & 4 \\
\hline Undergraduate junior (UJ) & 3 \\
\hline $\begin{array}{l}\text { Across undergraduate curriculum } \\
\text { (AUC) }\end{array}$ & 3 \\
\hline Undergraduate freshman (UF) & 3 \\
\hline Former students (FS) & 2 \\
\hline Undergraduate sophomore (USP) & 2 \\
\hline Graduate sophomore & 1 \\
\hline Practitioners (P) & 1 \\
\hline
\end{tabular}


The qualitative distribution of individual genres mentioned by the publications pedagogically-oriented confirms that in freshman and sophomore years one of the pedagogical goals has been writing to learn (i.e., computer laboratory tasks, reading mathematical texts, and weekly reports for solving problems with theoretical justifications). In junior and senior years, research-oriented writing has been incorporated (e.g., research reports) (table 4 ).

Table 4

The genres mentioned in different learning moments of the initiatives pedagogically-oriented

\begin{tabular}{|c|c|c|c|c|}
\hline Learning moment & Genre 1 & Genre 2 & Genre 3 & Genre 4 \\
\hline $\begin{array}{c}\text { Freshman } \\
\text { undergraduate }\end{array}$ & $\begin{array}{c}\text { Computing } \\
\text { laboratory tasks }\end{array}$ & & & \\
\hline $\begin{array}{c}\text { Sophomore } \\
\text { undergraduate }\end{array}$ & $\begin{array}{c}\text { Reading } \\
\text { mathematical texts }\end{array}$ & $\begin{array}{c}\text { Weekly reports for } \\
\text { solving problems } \\
\text { with theoretical } \\
\text { justifications }\end{array}$ & Lab reports & $\begin{array}{c}\text { Computing } \\
\text { laboratory tasks }\end{array}$ \\
\hline $\begin{array}{c}\text { Junior } \\
\text { undergraduate }\end{array}$ & Summaries & Research reports \\
$\begin{array}{c}\text { Senior } \\
\text { undergraduate }\end{array}$ & $\begin{array}{c}\text { Reports of formative } \\
\text { research experiences }\end{array}$ & & & \\
\hline $\begin{array}{c}\text { Writing across the } \\
\text { curriculum }\end{array}$ & Writing assignments & & & \\
\hline
\end{tabular}

9. What agendas are currently proposed on Engineering writing?

The analysis of the topics of the conclusion sections suggests that the three most frequent topics mentioned throughout the publications are:

a. Writing to learn is associated with improving student engagement (7 cases);

b. Writing to learn is correlating with passing the classes ( 7 cases);

c. Interdisciplinary work is an opportunity (6 cases).

The next case is an illustration of conclusions implying the trend in the approach "writing to learn". According to the evaluation of an Argentine pedagogic intervention that was relying on writing weekly reports, it seems that some of the students considered the approach very demanding:

\section{Example 9}

Article title: "Improvement of Mathematics teaching and learning in Bioengineering: a challenge assumed from action research" (2012)

A survey was designed and implemented to the students in the courses 2008, 2009 and 2010, with the purpose of evaluating their perception of the weekly report. The questions and results are shown in figure 3. $85 \%$ of the students regard the experience as useful and necessary for their performance, since it helped to understand concepts and correct mistakes. On the other hand, 15\% of the students said the experience was not positive, most of all for the lack of respect of individual learning pace of students and for being too demanding in terms of time.

The tendency of the publication in the approach "writing to learn" might be also related to fact the publications were primarily pedagogically-oriented or reporting research on pedagogical experiences. 
Furthermore, the third frequent mention in the conclusions related to positive evaluations of interdisciplinary work (6 cases) confirms that interdisciplinarity has been a feature of the initiatives/ studies undertaken (16 cases).

The specific conclusion about "Interdisciplinary work is an opportunity" emerged in 5 cases in publications pedagogically-oriented (3 are research on pedagogical experiences, and 2 are pedagogicallyoriented), and in 1 case a research-oriented article.

The analysis of the topics on limitations stated by the publications also suggests that the writing advocates demand certain conditions related to class sizes in the cases of initiatives/studies pedagogicallyoriented; for instance, the amount of students is mentioned in the following Argentine case as a hindering issue in incorporating writing as part of the Engineering courses:

\section{Example 10}

Article title: "Creating an educational research space in an Engineering department" (2009)

Regarding the negative aspects and difficulties in its implementation, "it is difficult to distribute the time between the control of individual work and group discussion to explain the subjects in which frequent errors of the group are detected". "The high number of students by section hinders a more personalized monitoring".

Furthermore, it is stated that despite the writing supports introduced by these initiatives, the students still struggle in developing audience awareness.

As for implications derived from the studies/ initiatives, the writing advocates envision studies to explore disciplinary features of writing and communication in Engineering as well as professional genres. This particular implication is regarded in the publications as useful to inform pedagogical initiatives across the curriculum and design teaching materials and resources. The following fragment illustrates these cases by presenting an excerpt of a Chilean study describing multisemiotic artifacts from a corpus of readings at $\mathrm{PhD}$ levels:

\section{Example 11}

Article title: "Academic and professional genre Variation across four disciplines: Exploring the pucv2006 corpus of Written Spanish" (2010)

Research studies as the one described here also have pedagogical implications concerning: (a) the selection of written genres, (b) the elaboration of teaching materials, and (c) the preparation of language tests of various kinds, such as the assessment of disciplinary contents and of specialized discourse comprehension.

Furthermore, this analysis also reveals that the authors of the publications are advocating for pedagogic initiatives that bridge academic and professional writing practices in Engineering, which might suggest that it is already acknowledged this double nature of writing and communication in the Engineering field (3 cases of publications research-oriented).

\section{Technical communication programs in the U.S.: teaching and research agendas}

Since the ultimate goal of this study is to provide a context to boost agendas for Latin-American Writing Studies in Engineering and the development of Technical Communication Programs in the region, the following section is framing technical communication programs in the U.S., which will be utilized, in the discussion section, to identify shared features and differences between the Latin-American endeavors and the U.S. programs. This contrast is useful to envision LatinAmerican research agendas by valuing what has been locally developed and identifying international debates in the field of Technical Communication to which Latin-American writing advocates can contribute.

\section{The status of the U.S. Technical Communication Programs}

Several studies have mapped the scope of the field of Technical Communication in order to understand the history, the influence of different disciplinary traditions, 
and tensions between theories and practices in academia and workplace settings (Selfe \& Selfe, 2012). Overall, the field is acknowledged as interdisciplinary, since it shares and borrows methods, theories, and even content areas from Design Communication, Speech Communication, Rhetoric and Composition, Psychology, Education, and Computer Science (Spilka, 2002; Rude, 2009). This interdisciplinarity might be related to an unformed disciplinary identity and the lack of external recognition that has been attributed to multiple causes: a) the relative newness of the field as an area of inquiry; b) the assumption that the field on technical communication offers "services", in both corporate and academic settings, for more dominant fields such as Engineering, Information Technology, and Business; and, c) the adjunct status of technical communication programs within the English departments (in which they are usually housed), and within the broad field of Rhetoric and Writing (Rude, 2009).

Universities often treat Business and Technical Communication Programs (BTC) similarly to first-year composition (FYC), that is, as a course about academic writing as a general domain instead of a professional or disciplinary practice. As happens in FYC courses, BTC courses for students who are not pursuing Engineering or Science as their majors perceive the classes as service courses, and their instructors must struggle for status and identity within their universities (Russell, 2007). Technical communication instructors have reported they often feel like outsiders within English departments. Regarding work conditions, technical communication instructors are typically hired as lecturers; however, sometimes instructors in writing programs are better situated in terms of status, community, and respect (Reave, 2004).

Diverse student population shapes the BTC programs. In technical communication courses, all the students are Engineering majors; whereas in courses offered outside the schools, students from other majors attend. A diverse student body is more typical for elective courses (Reave, 2004).

Furthermore, "writing to learn" and "learning to write" ${ }^{\prime \prime}$ are still part of the pedagogical debates in the field, because BTC courses are seen as more disciplinary or professionally orientated than first-year composition courses (FYC), which are mainly associated with general education classes. ${ }^{9}$ BTC research and pedagogy have mainly focused on workplace communication and preparing students for workplace communicative practices (Russell, 2007). As a result, these courses typically are comprised by a more cohesive student population in terms of their majors than those in liberal arts courses (FYC associated with general education) (Russell, 2007).

The academic unit housing the programs of technical communication is also an issue of debate mostly because of the diversity of approaches from humanities, professional, and science communication (Maylath, Grabill \& Gurak, 2010). For instance, since Departments of English offer "services" to Engineering majors, teaching this type of course is seen as outside of the main purpose of English departments. Therefore, technical writing instructors (and scholars) are seen as subservient to both Engineering and English but essentially at home in neither place (Yeats \& Thompson, 2010). Overcoming the tensions between English departments and technical communication programs is thus seen as an important issue in the agenda of the U.S. field (Bernhardt, 2002). The tensions might be overcome insofar as it is accepted that technical writing has humanistic value by exploring rhetorical features in science communication even under expectations of objectivity (Miller, 2004). Cultural beliefs tend to treat "technology" and "data" as fixed and unbiased objects, but these assumptions change if science production is acknowledged as a rhetorical act, that is, knowledge production as a result of interpersonal negotiations in interpreting evidence (Winsor, 1996).

Debates over the status of the field have therefore influenced research and teaching agendas. One of the visible debates is how to define the ideal practices of the field. If technical communication and writing simply draw on the best practices carried out by industry and other workplace settings, non-academic environments would be producing authoritative knowledge, which leaves a narrow intellectual space for the discipline. Instead, if technical communication and writing are more than instrumental means predetermined by others, 
academic knowledge on technical communication and writing can advise about qualities of workplace practices (Monberg, 2002; Boettger, \& Lam, 2013). Furthermore, under the importance of models on "expanding learning" (Bernhardt, 2002), ${ }^{10}$ a research agenda is needed to provide information about transitions and overlapping practices between industry and academic settings; this means that academia and workplaces should interact to boost knowledge propagation and innovation between these two contexts.

The research agenda of the field of Technical Communication must also include studies on what has been marginalized or silenced in order to democratize participation of those who have been seen as historically relegated in organizations (Thralls \& Blyler, 2002). Participatory research is one way to give voice to those who are being investigated (Thralls \& Blyler, 2002). This study of marginalization also includes the study of tacit system of values and commitments within bureaucratic hierarchies, high technologies, and corporate capitalism that are embedded in technical communication practices (Miller, 2004). This topic is part of cultural studies in which power and contradictions are explored as ongoing and emerging forces in interaction within organizations (Thralls \& Blyler, 2002).

\section{Technical communication and digital technologies}

Studies have also documented emerging technical communication practices because of the influence of digital technologies. Developments in mobile technology have encouraged more cooperative work that is contingent and not physically-situated. On one hand, more people can work anywhere by telecommuting, collaborating electronically, and running their own business with mobile phones and laptops; however, on the other hand, freedom to work anywhere often means isolation and difficulty to build trust and relationships with others, which brings restricted opportunities for collaboration and networking but opportunities for co-working. As a result, co-working is an emerging technical communication practice that has been recontextualized by other inter-organizational activities as freelancing, virtual teams, and peer production (Spinuzzi, 2012).

Because of the influence of digital technologies in technical communication practices, some scholars have claimed that the main goal of BTC programs is to increase students' marketability to be prepared for the job market, mainly by increasing their skills for documentation process in the age of cooperativetechnological interaction. Accordingly, practitioners are expected to learn problem-solving and analytical skills, writing ability, and flexibility to keep learning on new digital writing situations (Kim \& Tolley, 2004; Yeats \& Thompson, 2010). This is why computer literacy is visible in the pedagogical agendas. There are different types of courses: a) skill courses for every day computer literacy at workplaces; b) courses on hardware and software for technical communication practices; c) courses on desktop publishing or graphic design programs that are focused on costeffective productions for organizations; d) publication management courses; e) computer intensive instruction in introductory writing courses; and, f) computer literacy courses to build critical awareness on digital reading and writing practices. Pedagogies on critical computer literacy particularly advocate for ideological analysis of literacy practices surrounding computer usage against to computer-skills pedagogies (Selber, 2004).

\section{Subject matter of the courses: science communication, professional genres, research skills, and journal publication}

Besides including digital communication practices in the curriculum, pedagogical agendas also stress the role of drawing in learning science. Students are encouraged to represent knowledge through drawing, observation, recording, and making inferences as opportunities to learn inductively on scientific concepts. Different goals are pursued: a) encouraging students to produce visual texts; b) increasing awareness of rhetorical effects of graphics and images in science (semiotic realities created by disciplinary communities) rather than groups of facts (Lerner, 2009). 
There are, for instance, pedagogical experiences in which students are taught about how scientists make complex decisions in designing experiments and reporting quantitative data for creating claims while addressing their peers. Students are supported for understanding differences between "raw data" (i.e., jots, plots, notes, outputs, visual traces produced in labs) and "evidence" for publications and communications ("selected data") (Poe, Lerner \& Craig, 2010). Systematizations show that students struggle in learning how to gain confidence from data, decide the best "evidence" for dissemination, and deal with software or other technical issues while interpreting data; especially because students tend to believe that there is a "correct way" to present visual data instead of creating visual evidence rhetorically-oriented. Therefore, these types of interventions help students to a) make decisions according to their audiences by selecting a "meaningful" subset of "raw data" (i.e., using data to "make a case" of their work); b) describe detailed explanations of the findings; and, c) avoid forcing data to fit in a theory to rather identify "interesting findings" (Poe, Lerner \& Craig, 2010).

Regarding Engineering genres to teach, proposals, progress reports, and completion reports are mentioned (Artemeva, 2005). Job applications and cover letters are also suggested as contents for upper division courses, because freshman or junior students have no experience in workplace cultures. Thus, these students have no incentive to look carefully and reflectively at past experiences to find applicable strategies; ultimately, these writing tasks might have no relevance beyond the grade for novice students (Quick, 2012).

Teaching academic research skills for workplaces is also highlighted in the pedagogical agendas through, for instance, encouraging students' publication of capstone experiences that address audiences beyond classrooms. These initiatives are undertaking by the following stages: a) literature review and research about a specific topic of the field; b) oral presentations for department staff and guests (practitioners); c) conference presentations; and, d) journal submissions. These initiatives also advocate for journal internships in which students learn how to write to be published and how to manage the publishing backstage (i.e., the administrative side of communicating with reviewers and authors, as well as the technical side of journal production by web design, content management, website updating, and e-journal promotion) (Ford \& Newmark, 2011).

\section{Teaching technical communication from a rhetorical approach}

Teaching on technical writing and communication as a rhetorical practice is strongly encouraged to defy the positivist view of knowledge. Much technical writing teaching maintains the legacy of positivist perspectives by focusing on style, organization, and tone; audience analysis in this perspective is mostly limited to adapting vocabulary of texts. This approach reinforces the view that scientists transmitted "physical realities" by writing (e.g., emphasizing the use of strategies as impersonal voice). Conversely, within rhetorical approaches, one of the subject matters must be "science as argument", which implies learners of technical communication become persuasive professionals embedded in rhetorical situations of scientific and technological domains (Miller, 2004).

In this approach, learning experiences must include projects to interact with different audiences and conduct shared assignments (i.e., across disciplines, different degrees of expertise, academic and industry audiences, different types of stakeholders within and across organizations). In shared assignments, language assumes the function of satisfying a real need outside of the language classroom (Tatzl, Hassler, Messnarz \& Flühr, 2012). However, this effort is challenging because of the heterogeneity of student population in classrooms in terms of their expertise and field affiliations, especially in the case of BTC courses of general education requirement (McDaniel \& Steward, 2011). Team teaching among researchers, practitioners, language instructors, and disciplinary instructors is acknowledged as a pedagogical strategy, but it is rarely implemented due to high costs. In these types of initiatives it is not enough to expose students to diverse audiences; even when they are immersed in an actual workplace setting and are assigned authentic 
writing tasks, students might not fully understand the implications of their work because they are accustomed to write for pleasing a single-person audience (the instructor) to earn a grade. Therefore, students still need scaffolding when writing for real workplace audiences (Quick, 2012).

Also, studies of communication skills required by workplace settings have called for curriculum reforms to meet needs of organizations (Reave, 2004). One of the goals is to design learning experiences that expose students to diverse communicative and writing practices according to different organizational positions that students could achieve in their professional future, which includes internships and interdisciplinary curriculum that teach about management and business reasoning (McDaniel \& Steward, 2011).

Cross-cultural rhetorical studies of professional communication explore workplace literacies and organizational cultures. Thatcher (1999; 2000; 2001) studied differences in cultural expectations between U.S. and South-American professionals with respect to the context provided in oral and written communication, the abstraction or particularity, and the cultural functions of writing and orality. Such rhetorical similarities and differences can be explained by cultural assumptions about authority, leadership, collectivism, individualism, and work relationships (Thatcher, 2005).

Based on surveys, ethnographies, and discoursebased interviews of documents written in English and Spanish, Thatcher (1999) claims that rhetorical preferences of every culture must be understood by communication professionals to anticipate challenges, such as: translating documents of intercultural companies, writing procedures and policies in different languages, and understanding diverse interpretations of regulations mediated by documents. Thatcher's advocacy for intercultural rhetorical studies highlights research approaches in which U.S. models of rhetoric and communication cannot be used as means for cultural domination; instead, comprehensive and emic research methods beyond textual analysis of documents are suggested to comprehend rhetorical cultures. $\mathrm{He}$ advocates incorporating researchers from the regions that will be investigated and establishing a common ground in which to operationalize and compare the variables of both cultures in the intercultural context (Thatcher, 1999; 2000; 2001; 2005).

\section{Assessment agendas}

Regarding assessment in technical communication programs, some scholars suggest institutional assessment of curriculum and learning outcomes according to institutional values of universities; this type of assessment can provide insights for planning (Allen, 2010). Concerning student performance and learning outcomes, assessment on "polymorphic literacy" (i.e., writing as a performance that involves both images and language) is also advised. Moreover, learning assessment of changes in students' performances across time is also recommended; for instance, through validated rubrics to be applied to students' writing samples (Coppola \& Elliot, 2010). ${ }^{11}$

\section{Discussion}

In Latin America there is no specific field equivalent to Technical Communication as developed in the U.S.; however, there is a body of emerging Latin-American writing initiatives and studies in Engineering. This section identifies shared features and differences between the Latin-American endeavors and the U.S. programs by contrasting the results of the analysis of 22 publications on Latin American Engineering writing and the literature review on Technical Communication in the U.S. above. This section follows Thatcher's call for conducting crosscultural comparisons by honoring local conditions pertaining to professional communication, higher education, and Engineering writing.

\section{The status of the field in Latin America}

The analysis suggests that Writing Studies in Engineering is an emerging field in the Latin-American region (less than a decade in existence) and with a specific trend of being pedagogically-oriented (Añino et al. 2009; 2010; 2012; 2013; López \& Ramírez, 2012; Natale \& Stagnaro, 2012; Stagnaro \& Jauré, 2013; López 
\& Martínez, 2014; López \& Ramírez, 2014; García et al., 2014; Gómez, 2014; Sánchez \& Valderrama, 2014; López y Molina, 2015).

The initiatives seem to be institutionalized as part of departmental supports, curriculum reforms, and faculty development programs (Añino et al. 2009; 2010; 2012; 2013; Natale \& Stagnaro, 2012; Stagnaro \& Florencia, 2013; García et al., 2014; Gómez, 2014; Sánchez \& Valderrama, 2014; Natale \& Stagnaro, 2015). In contrast to the U.S. scholarship, the Latin-American publications analyzed do not report any quarrels regarding the status of the technical communication instructors, programs, or initiatives (Russell, 2007; Rude, 2009; Reave, 2012).

The analysis of Latin-American publications that report initiatives pedagogically-oriented suggests that the field has emerged primarily focused on the approach "writing to learn"; however, designing writing initiatives that prepare students for workplace communicative practices (Russell, 2007) emerges as a topic of the conclusions, limitations, and implications of the publications analyzed. For instance, as part of the conclusion sections, some of the publications aimed at a) exploring if professional genres have been taught in college years (Natale \& Stagnaro, 2015; Natale, 2015); b) differentiating between professional genres and academic genres (Parodi, 2010a); and, c) collecting samples of professional genres from instructors in senior years (Añino et al., 2010).

Regarding limitations and implications related to professional genres, the publications mentioned, for instance, that there is a lack of descriptions of professional genres to inform curriculum design (Natale \& Stagnaro, 2012); thus, further research about professional genres is suggested (Natale \& Stagnaro, 2012; Stagnaro, Chiodi \& Miguez, 2012). Moreover, incorporating professionallyoriented tasks from freshman years is also stated as an implication of the publications (Parodi, 2010a; Natale \& Stagnaro, 2015; Natale; 2015).

The analysis of conclusions and limitations suggests that in the Latin-American case it is not visible, at least in this sample, tensions related to humanities, professional, and science communication approaches mentioned in the North American literature.
Furthermore, in the Latin-American case, interdisciplinarity (e.g., writing instructors and disciplinary professors or practitioners) is praised through topics of the conclusions (Añino et al., 2011; Gómez, 2014; López \& Martínez, 2014; López \& Molina, 2015; Natale \& Stagnaro, 2015) and envisioned as a further implication (Añino et al., 2010). This Latin-American climate in favor of interdisciplinarity might be also associated with the most frequent type of pedagogical goal undertaken thus far: "writing to learn", since the type of writing assignments might count as low-stake writing assignments (i.e., summaries and weekly reports for solving problems in table 1 and 3) that do not necessarily introduce room for critical stances or contradictory systems of values either for students or instructors involved in the initiatives (for both, Engineering professors and writing advocates). Possibly, when teaching on professional and scientific writing and communication is incorporated in the Latin-American region, different negotiations with disciplinary professors and practitioners might create spaces to start conversations about objectivity or rhetorical production of professional and scientific knowledge in Engineering.

As happens in the U.S. scholarship, there is an interest reported by some of the Latin-American publications in pursuing research agendas for providing information about transitions and overlapping practices between industry and academia (Bernhardt, 2002; Parodi, 2010; Natale, 2015; Natale \& Stagnaro, 2015). One of the Latin-American publications analyzed stresses as a limitation that teaching professional genres is artificial (Natale, 2015), and in three cases the publications claim for bridging academic writing practices and professional writing practices (Parodi, 2010a; Natale \& Stagnro, 2015; Natale, 2015).

The U.S. cultural studies making visible and complicating tacit values and commitments of bureaucratic hierarchies, high technologies, and corporate capitalism embedded in the field (Thralls \& Blyler, 2002; Miller, 2004) did not emerge from the Latin-American sample. Further analysis of LatinAmerican publications associated with organizational communication, for instance, might provide insights 
on this particular issue about critical studies on writing and communication practices within local companies.

The emphasis on writing to learn and the emerging call for further research on professional genres might suggest that in the Latin-American case the debate on what should be the goal of the writing courses in Engineering is not yet present (at least in the sample analyzed), such as the goal of increasing students' marketability (Selber, 2004). This conflict between professional or humanistic role of writing courses might be further traced in Latin-American publications that report studies or initiatives on freshman writing courses, since this is the most frequent pedagogic intervention in the region (see ILEES project at http:// english.ilees.org/).

The overall analysis shows that research and initiatives on Engineering writing are advocating primarily for writing to learn and the tendency throughout the publications is to mention genres as individual texts to support student learning (i.e., writing assignments, summaries, computer laboratory tasks, reading mathematical texts, and weekly reports for solving problems with theoretical justifications). These trends suggest that the Latin-American writing advocates in Engineering might broaden research scopes by incorporating theoretical frameworks for:

a. exploring and understanding different roles of writing across time and curriculum in student learning and by Engineering subfields (e.g., differences over time among writing summaries, weekly reports for solving-problems, and lab reports in learning the discipline versus writing professional or research genres); and,

b. exploring theoretical approaches to understand genres beyond individual texts to embed them as part of systems of activity ${ }^{12}$ (i.e., genre repertoires and genre systems ${ }^{13}$ ), which implies to rethink curriculum initiatives and studies under the assumption that students as further practitioners of their disciplines will be exposed to a spectrum of roles as genres users (either as readers or writers) and as part of complex overlapping activities impacted by issues of hierarchy and power within organizations.

\section{Digital technologies}

Regarding issues on computer literacy, the publications of the sample mentioned computers only in three cases, but they were related to the same Argentine experience (Añino et al., 2010a; 2010b; 2012; 2013). In this case, computer literacy was not part of the teaching contents (Selber, 2004); instead, computer assignments are means to support students' learning (i.e., writing to learn).

\section{Subject matter of the courses}

Specific experiences of research or pedagogical initiatives for creating data and evidence in scientific writing in Engineering (Poe, Lerner \& Craig, 2010) did not emerge from the sample. However, some LatinAmerican publications report initiatives in which verbal and mathematical systems are seen as articulated to support student learning, or in which research about Engineering texts implies adopting a multimodal approach (Parodi, 2010c).

In the U.S. scholarship, there is a debate about when and how to teach genres related to workplace cultures such as job-applications and cover-letters (Quick, 2012). The analysis of the Latin-American publications (table 3 ) suggests that these types of genres are not part of the initiatives/studies of the sample. Despite the size and type of the sample (22 publications of a convenience sampling), this finding might be explained by features either of the higher education systems (by further analyzing to what extent in LatinAmerican Engineering majors, students are exposed to internships), or features of written genres embedded in job applications (by further analyzing written genres requested, if any, in Latin-American job markets).

The U.S. scholarship of teaching on science communication and research skills (Ford \& Newmark, 2011) might be further explored in the Latin-American case by contextualizing what counts as scientific knowledge production and to what extent this is related 
to higher education in general and to Engineering majors in particular. These particular U.S. experiences for teaching genre practices that merge scientific and professional audiences (e.g., literature reviews or oral presentations that are addressing simultaneously academic and industry audiences) (Ford \& Newmark, 2011) continue nourishing conversations about the rhetorical nature of science and technology (science as argument) (Miller, 2004). In this regard, it is interesting to mention that in the Latin-American case, two pedagogically-oriented publications mentioned as limitation that students struggle in developing audience awareness (López \& Ramírez, 2012; 2014); this difficulty might be also associated with assigning writing activities that are exclusively addressing instructors (writing to learn). Therefore, further research initiatives might collect data to compare how audience awareness is developed over time according to types and amounts of learning opportunities in which students have to address either interdisciplinary, academic, and industry audiences.

\section{Assessment agendas}

The U.S. scholarship has acknowledged the importance of conducting assessment of curricula and learning outcomes of the programs according to systems of values of the institutions and majors (Allen, 2010; Coppola \& Elliot, 2010). In the case of the Latin-American publications analyzed, the writing advocates are already pointing out the need of conducting developmental research on students writing and genre awareness of faculty members who have been participants of the interdisciplinary writing initiatives in Engineering majors (Natale \& Stagnaro, 2012; Stagnaro \& Jauré, 2013).

\section{Conclusion}

This article aimed at exploring features of LatinAmerican writing initiatives in Engineering reported by publications (journal articles and oral communications) from Spanish-speaking countries to map programs pursued in the region and then provide a context to envision research agendas for Latin-American Writing Studies in Engineering and the development of Technical Communication Programs in the region.

The data suggest that the Latin-American movement might have started under the approach of writing to learn. Possibly, it might be expected that when these Latin-American initiatives and studies incorporate research and pedagogic interventions on professional writing and communication, novel debates will emerge particularly associated with tensions and goals of educating under humanistic and technical approaches of the courses and also regarding the rhetorical nature of science and technology; this climate might further allow integrating critical approaches in the advancement of the Latin-American field.

Furthermore, the trends of the analysis reveal that the Latin-American writing advocates in Engineering might broaden research scopes by incorporating theoretical frameworks for a) exploring and understanding different roles of writing across time/ curriculum in student learning and by Engineering subfields and, b) exploring theoretical approaches to understand genres beyond individual texts (genre repertoires and genre systems).

This analysis also makes visible the need of further exploring features of higher education systems and economic conditions under which science and technology are related to Engineering knowledge production as an important context of the emergence of technical communication programs and initiatives beyond the U.S. Additionally, the study confirms the importance of conducting research on development of writing and communication in Latin-American Engineering majors, in general, and in the actual initiatives already undertaken, in particular, by identifying regional disciplinary learning expectations on writing and communication over time.

\section{Acknowledgments}

I would like to thank my Latin-American colleagues who shared their publications when I was collecting the data for this project. This project was also possible with the financial support from Fulbright-Colombia, the 
Colombian Department of Science, Technology, and Innovation (Colciencias), Universidad Autónoma de Occidente (UAO), and University of California, Santa Barbara (UCSB).

\section{Notes}

1. This project collected information from 389 initiatives reported voluntarily by an online survey applied between summer 2012 and fall 2013 to scholars from aforementioned countries. The study started as a research internship in the doctoral program pursued by the author along with a Chilean colleague, Natalia Âvila, under the guidance of Professor Charles Bazerman from University of California, Santa Barbara (UCSB). Later, other Latin American scholars joined the research group: Vera Lúcia Cristovão, Ana Valeria Bisseto, and Francini Correa from Universidade Estadual de Londrina, Mónica Tapia from Universidad Católica de la Santísima Concepción, Chile, and Federico Navarro from Universidad de Buenas Aires and National Council of Scientific and Technical Research (CONICET) in Argentina.

2. For instance, Signo y Seña (Universidad de Buenos Aires, Argentina), Signos (Pontificia Universidad Católica de Valparaíso, Chile) and Lenguaje (Universidad del Valle, Colombia). Regarding networks and associations, since 2006, a Colombian network for Reading and Writing in Higher Education (REDLEES in Spanish) was founded, recently; in 2014, the first Latin American Network of Writing Centers and Programs was established, and the other associations existing before 2006 have been primarily related to Linguistics studies and not necessarily focused on Higher Education levels, for instance, UNESCO chairs for reading and writing in Argentina, Chile, Colombia, Mexico, Venezuela, and Puerto Rico.

3. This article is derived from the doctoral thesis titled "Mapping expectations on writing and communication in engineering within a regional context: accounts from a Latin-American case" conducted under the guidance of Professors Charles Bazerman, Linda Adler-Kassner, and Karen Lunsford of University of California, Santa Barbara (UCSB), United States.

4. The events were:

a)Simposio internacional GICEOLEM "Investigar la enseñanza de la lectura y la escritura para aprender en distintas disciplinas del nivel medio y superior" August, 11, 12, and 13, 2014 in Buenos Aires, Argentina.

b) V Encuentro Internacional y VI Nacional de Lectura y Escritura en la Educación Superior. August 27, 28 y 29, 2014, in Bucaramanga, Colombia.
5. See the project at: http://www.utp.edu.co/vicerrectoria/ investigaciones/publicaciones-lectura-escritura/

6. In this section some fragments of the actual publications are used to illustrate the analysis. Since most of the original data is in Spanish, the cases were translated into English by the author.

7. This symbol (...) indicates that the analyst has eliminated fragments of the original case.

8. Broadhead (1999, as cited in Carter el al. 2007), summarize these two approaches "writing to learni.e., writing as a means of acquiring information, understanding concepts, and appreciating significance in any discipline... [versus] learning to write-i.e., acquiring the socially-mediated communication skills and genre knowledge appropriate to a specific discipline".

9. General Education is a distinctive feature of the U.S. Higher Education system. According to Adler-Kassner (2014), general education has been an effort within the U.S. academy to "create the dynamic tension between liberal learning, professional training, and Disciplinarity" (p. 438). In other higher education systems, core courses (many of them related to Humanities, Social Sciences, writing in mother tongue and second language, and statistics) might count as this U.S. educational goal of seeing core education as less disciplinary-oriented.

10. The theories on "expanding learning" assume that individuals are change agents who participate either in crossing-concurrent contexts (i.e., courses in the same semester or university coursework and a parttime job), or sequential contexts (e.g., sequences of courses in a major, high school to college, or from a college program to a post-graduation job) (TuomiGröhn \& Engeström, 2003). By participating in several contexts, individuals may engage in both routinized (low-road) and transformative (high-road) forms of transfer (reutilizing knowledge learned in concurrent or sequential contexts) as they draw on and utilize prior knowledge and learning experiences (Moore, forthcoming). This model explains how transitions and knowledge propagation ensue as opportunities to overcome discontinuities and contradictions of participating in several contexts (Rounsaville, 2012), while also might provide novel ideas for regenerating status quo or traditions.

11. The assessment agendas in the U.S. for technical communication programs have been highly influenced by accreditation agencies such as ABET, which in pursuing its mission has included issues of communication and writing as part of the factors involved "(...) in assuring quality and stimulating innovation in applied science, computing, engineering, 
and engineering technology education”. Information taken from: ABET Vision. (n.d.). Retrieved February 25, 2016, from http://www.abet.org/about-abet/visionand-mission/

12. Theoretical category to explain social activity and its organization/reproduction by making visible the overlap and natural contradictions emerging from the interaction between a) social goals of communities/ groups and personal motives of individuals within and across organizations/communities/groups, with b) division of labor, social roles, hierarchies and power, systems of values, status quo vs. innovation, and access/ creation of artifacts (either material or symbolic).

13. Cf. Spinuzzi, 2012; Bawarshi \& Reiff, 2010; Russell, 2010; Freedman, 2006; Tardy, 2009; Artemeva, 2006; and, Devitt, Bawarshi \& Reiff, 2003.

\section{References}

Adler-Kassner, L. (2014). Liberal Learning, Professional Training, and Disciplinarity in the Age of Educational 'Reform"': Remodeling General Education." College English, 76(5), 436-457.

Allen, J. (2010). Mapping institutional values and the technical communication curriculum: A strategy for grounding assessment. In Hundleby, M. N., \& Allen, J. (Eds.). Assessment in technical and professional communication. (39-56). Baywood Publishing Company.

Añino, M. M., Merino, G., Miyara, A., Perassi, M., Ravera, E., Pita, G., \& Waigandt, D. (2013). Early error detection: an action-research experience teaching vector calculus. International Journal of Mathematical Education in Science and Technology, 45(3), 378-395.

Añino, M. M., Ravera, E., Waigandt, D., Miyara, A., Pita, G., \& Perassi, M. (2009).Creando un espacio de investigación educativa en una facultad de ingeniería. Unpublished manuscript, Memorias del III Congreso Nacional de Educación. Construcciones y perspectivas. Miradas desde y hacia América Latina., Universidad Nacional Entre Ríos, Santa Fé Argentina.

(2010a). Interdisciplinarity: Perspectives for the design of Didactic strategies in Engineering. In Proceedings of Turkey's vision 2023 conference series (123-128).

(2012). Mejorar la enseñanza y el aprendizaje de la Matemática en Bioingeniería: Un desafío asumido desde la investigación-acción. Revista Argentina de Enseñanza de la Ingeniería, (21), 35-45.

Añino, M. M., Waigandt, D. M., Perassi, M., Pita, G., Miyara, A., Klimovsky, E. \& Canavelli, J. C. (2010b, April). Action Research: A way to generate new approaches to teaching mathematics in Bioengineering. In IEEE EDUCON 2010 Conference (1385-1390). IEEE.

Artemeva, N. (2005). A Time to Speak, a Time to Act A Rhetorical Genre Analysis of a Novice Engineer's Calculated Risk Taking. Journal of Business and Technical Communication, 19(4), 389-421.

(2006). Approaches to Learning Genres: A Bibliographical Essay. In Natasha Artemeva and Freedman Aviva (Eds.), Rhetorical genre studies and beyond (15-87). Canada: Inkshed Publications.

Base internacional bibliográfica sobre Lectura y Escritura - Inicio. (n.d.). Retrieved October 15, 2015, from: http://www.utp.edu.co/vicerrectoria/investigaciones/ publicaciones-lectura-escritura/

Bawarshi, A. S., \& Reiff, M. J. (2010). Genre in Linguistic Traditions: English for Specific Purposes. In Genre: An introduction to history, theory, research, and pedagogy. (41-56). West Lafayette, IN: Parlor Press.

Bernhardt, S. A. (2002). Active-practice: Creating productive tension between academia and industry. In Mirel, B., \& Spilka, R. (Eds.). Reshaping technical communication: New directions and challenges for the 21st century. (81-90). Routledge

Boettger, R. K., \& Lam, C. H. R. I. S. (2013). An Overview of Experimental and Quasi-Experimental Research in Technical Communication Journals (1992-2011). Professional Communication, IEEE Transactions on, 56(4), 272-293.

Carter, M., Ferzli, M., \& Wiebe, E. N. (2007). Writing to learn by learning to write in the disciplines. Journal of Business and Technical Communication, 21(3), 278302.

Cisneros, M. (2014). Base internacional bibliográfica sobre Lectura y Escritura - Inicio. Retrieved September 04, 2016, from http://www.utp.edu.co/vicerrectoria/ investigaciones/publicaciones-lectura-escritura/

Devitt, A. J., Bawarshi, A., \& Reiff, M. J. (2003). Materiality and genre in the study of discourse communities. College English, 541-558.

Elliot, N. \& Coppola, N. (2010). Assessment of graduate programs in technical communication. In Hundleby, M. N., \& Allen, J. (Eds.). Assessment in technical and professional communication. (127-161). Baywood Publishing Company.

Ford, J. D., \& Newmark, J. (2011). Emphasizing Research (Further) in Undergraduate Technical Communication Curricula: Involving Undergraduate Students with an Academic Journal's Publication and Management. Journal of Technical Writing and Communication, 41(3), 311-324. 
Freedman, A. (2006). Interaction between Theory and Research: RGS and a Study of Students and Professionals Working “in Computers”. In Artemeva, N., \& Freedman, A. (Eds.). Rhetorical genre studies and beyond. (87-101). Inkshed Publications.

García, D., Nieto, N., \& Vera, A. (2014). Integración de la lectura y la escritura en el curso de laboratorio de dispositivos electrónicos de ingeniería electrónica. Unpublished manuscript, $\mathrm{V}$ encuentro internacional y IV nacional de lectura y escritura en la educación superior, Red de Lectura y Escritura en la Educación Superior (REDLEES), Colombia.

Gardner, S., \& Nesi, H. (2012). A classification of genre families in university student writing. Applied linguistics, 34(1), 25-52.

Gómez, D., (2014). El cambio de concepción sobre escritura del asesorado tras la revisión entre pares: una experiencia del grupo de apoyo para la lectura y escritura en la facultad de ingeniería. Unpublished manuscript, $\mathrm{V}$ encuentro internacional y IV nacional de lectura y escritura en la educación superior, Red de Lectura y Escritura en la Educación Superior (REDLEES), Colombia.

Herrington, A. \& Moran, C. (2005). The Idea of Genre in Theory and Practice: An Overview of the Work in Genre in the Fields of Composition and Rhetoric and New Genre Studies. In Anne Herrington and Charles Moran (Eds.). Genre across the curriculum. (pp. 1-20) Utah State University Press.

ILEES English. (n.d.). Retrieved October 15, 2015, from http://english.ilees.org/

Kim, L., \& Tolley, C. (2004). Fitting academic programs to workplace marketability: Career paths of five technical communicators. Technical communication, 51(3), 376386.

Lerner, N. (2009). The idea of a writing laboratory. SIU Press.

López, K. \& Martínez, J., (2014). Escribir para aprender y comunicar en la asignatura Procesos de Ingeniería de Software. Trabajo colaborativo entre docentes de lengua y docentes de las disciplinas. Unpublished manuscript, $\mathrm{V}$ encuentro internacional y IV nacional de lectura y escritura en la educación superior, Red de Lectura y Escritura en la Educación Superior (REDLEES), Colombia.

López, K. \& Molina, V., (2015). Orientación y evaluación de la escritura en asignaturas disciplinares. Experiencia de trabajo colaborativo docente. Trabajo colaborativo entre docentes de lengua y docentes de las disciplinas. Unpublished manuscript, Encuentro Internacional de Lectura y Escritura, Ecuador.
López, G., \& Ramírez, R. (2012). Los resúmenes como estrategia de aprendizaje. Revista Lenguaje, 40(2), 315350.

Maylath, B., Grabill, J., \& Gurak, L. J. (2010). Intellectual fit and programmatic power: Organizational profiles of four professional/technical/scientific communication programs. Technical Communication Quarterly, 19(3), 262-280.

McDaniel, R., \& Steward, S. (2011). Technical communication pedagogy and the broadband divide: Academic and industrial perspectives. Complex worlds: Digital culture, rhetoric, and professional communication, (195-212). NY: Baywood.

Miller, C. R. (2004). A humanistic rationale for technical writing. Central works in technical communication, 4754. Oxford University Press.

Monberg, J. (2002). Science and technology studies as a research method. In Gurak, L. J., \& Lay, M. M. (Eds.). (2002). Research in technical communication. (211229).Greenwood Publishing Group.

Moore. L. J. (forthcoming). Five Essential Principles about Writing Transfer. In Critical Transitions: Writing and the Question of Transfer, ed. Jessie Moore and Chris M. Anson. Parlor Press. Forthcoming 2016.

Narváez, E. (2014). Estudios de la escritura en América Latina: Trazando un mapa de logros y desafíos. V Encuentro Internacional y VI Nacional de Lectura y Escritura en la Educación Superior. Universidad Autónoma De Bucaramanga. Colombia.

(2015, March 20). Practices emerging from writing centers and writing programs of Latin American initiatives. Speech presented at Conference on College Composition and Communication Annual Convention in Marriott, Tampa, Florida. USA.

Natale, L., \& Stagnaro, D. (2012). Desarrollo de habilidades de lectura y escritura en la trayectoria académica del ingeniero: la experiencia de un programa desafiante e innovador. Facultad Regional San Rafael-Universidad Tecnológica Nacional.

(2015). Alfabetización profesional durante la carrera universitaria: entre la universidad y la empresa. Itinerarios Educativos, (7), 11-28.

Navarro, F., Avila, N., Tapia, M., Cristovão, V., Moritz, M., Narváez, E., Bazerman, Ch., (2016). Panorama histórico y contrastivo de los estudios sobre lectura y escritura en educación superior publicados en América Latina. Revista Signos (49). Forthcoming September, 2016.

Paoloni, P. \& Chiecher, A. (2013). Experiencias de formación y de inserción laboral de ingenieros: las voces de los protagonistas desde una investigación 
biográfica. Innovación educativa (México, DF), 13(61), 22-44.

Parodi, G. (2010). Academic and Professional genre variation across four disciplines: exploring the PUCV2006 corpus of written Spanish. Linguagem em (Dis) curso, 10(3), 535-567.

(2010b). La organización retórica del género Manual a través de cuatro disciplinas: ¿cómo se comunica y difunde la ciencia en diferentes contextos universitarios?. Boletin de Linguistica, 22(33), 43-69.

(2010c). Multisemiosis y lingüística de corpus: artefactos (multi)semióticos en los textos de seis disciplinas en el corpus pucv-2010. RLA. Revista de lingüística teórica y aplicada, 48(2), 33-70.

Poe, M., Lerner, N., \& Craig, J. (2010). Learning to communicate in science and engineering: Case studies from MIT. MIT Press.

Quick, C. (2012). From the Workplace to Academia: Nontraditional Students and the Relevance of Workplace Experience in Technical Writing Pedagogy. Technical Communication Quarterly, 21(3), 230-250.

Reave, L. (2004). Technical Communication Instruction in Engineering Schools A Survey of Top-Ranked US and Canadian Programs. Journal of Business and Technical Communication, 18(4), 452-490.

Rounsaville, A. (2012). Selecting Genres for Transfer: The Role of Uptake in Students' Antecedent Genre Knowledge. In Composition Forum (Vol. 26). Association of Teachers of Advanced Composition. Retrieved from: http://files.eric.ed.gov/fulltext/ EJ985811.pdf

Rude, C. D. (2009). Mapping the research questions in technical communication. Journal of Business and Technical Communication, 23(2), 174-215.

Russell, D. R. (2007). Rethinking the Articulation Between Business and Technical Communication and Writing in the Disciplines Useful Avenues for Teaching and Research. Journal of Business and Technical Communication, 21(3), 248-277.

(2010). Writing in multiple contexts: Vygorskian CHAT meets the phenomenology of genre. In C. Bazerman, R. Krut, K. Lunsford, S. McLeod, S. Null, P. Rogers, et al. (Eds.), Traditions of writing research (pp. 353-364). New York: Routledge.

Sánchez, C. R. \& Valderrama, J. (2014). Incidencia del grupo de apoyo para la lectura y escritura en la construcción de conocimiento de estudiantes de ingeniería. Unpublished manuscript, $\mathrm{V}$ encuentro internacional y IV nacional de lectura y escritura en la educación superior, Red de Lectura y Escritura en la Educación Superior (REDLEES), Colombia.
Selber, S. (2004). Challenges facing technical communication teachers in the computer age. In Selber, S. A. Central works in technical communication. (449-466). Oxford University Press.

Selfe, R. \& Selfe, C. (2012). What Are the Boundaries, Artifacts, and Identities of Technical Communication? In Johnson-Eilola, J., \& Selber, S. A. (Eds.). Solving problems in technical communication. (19-50). University of Chicago Press.

Spilka, R. (2002). Becoming a profession. In Mirel, B., \& Spilka, R. (Eds.). Reshaping technical communication: New directions and challenges for the 21st century. (97111). Routledge.

Spinuzzi, C. (2012). Genre and Generic Labor. In Bazerman, Charles, Dean, Chris, Early, Jessica, Lunsford, Karen, Null, Suzie, Rogers, Paul, and Stansell, Amanda (Eds.). International Advances in Writing Research: Cultures, Places, Measures. Perspectives on Writing. (pp. 487505). Fort Collins, Colorado: The WAC Clearinghouse and Parlor Press

Spinuzzi, C. (2012). Working Alone Together Coworking as Emergent Collaborative Activity. Journal of Business and Technical Communication,26(4), 399-441.

Stagnaro, D., Chiodi, F., \& Miguez, P. (2012). Desarrollo de competencias comunicativas en la formación del ingeniero: una propuesta interdisciplinaria. InActas del I Congreso Argentino de Ingeniería (CADI) y del VII Congreso Argentino de Enseñanza de la Ingeniería (CAEDI).

Stagnaro, D., \& Jauré, M. (2013). Géneros profesionales en la formación del ingeniero. Unpublished manuscript, VI Congreso de Ingeniería Industrial, Facultad Regional San Rafael - Universidad Tecnológica Nacional, Argentina.

Stagnaro, D., \& Natale, L. (2015). Géneros y formación ingenieril: dela universidad a la industria. Magis. Revista Internacional de Investigación en Educación, 8(16), 91108.

Tardy, C. \& Swales, J. (2009). From, text organization, genre, coherence, and cohesion. In Bazerman, C. (Ed.). (2009). Handbook of research on writing: History, society, school, individual, text. (pp. 565-581). Routledge.

Tatzl, D., Hassler, W., Messnarz, B., \& Flühr, H. (2012). The Development of a Project-Based Collaborative Technical Writing Model Founded on Learner Feedback in a Tertiary Aeronautical Engineering Program. Journal of Technical Writing and Communication, 42(3), 279-304.

Thatcher, B. L. (1999). Cultural and rhetorical adaptations for South American audiences. Technical communication, 46(2), 177-195. 
244 Elizabeth Narváez-Cardona, Latin-American Writing Initiatives in Engineering from Spanish-speaking Countries

(2001). Issues of validity in intercultural professional communication research. Journal of Business and Technical Communication,15(4), 458-489.

(2000). L2 professional writing in a US and South American context. Journal of Second Language Writing, 9(1), 41-69.

(2005). Situating L2 writing in global communication technologies. Computers and Composition, 22(3), 279-295.

. (2009). Understanding digital literacy across cultures. In Digital literacy for technical communication: 21st century theory and practice (169-198).

Thralls, C., \& Blyler, N. (2002). Cultural studies: An orientation for research in professional communication. In Gurak, L. J., \& Lay, M. M. (Eds.). Research in technical communication. (185-209). Greenwood Publishing Group.

Trujillo, J. C. (2015). Dificultades de la escritura de informes de investigación formativa en la educación superior en facultades de Ingeniería. Polisemia, (14), 12-23.

Tuomi-Gröhn, T. \& Engeström, Y. (2003). Conceptualizing transfer from standard notions to developmental perspectives. In T. Tuomi-Gröhn \& Y. Engeström (Eds.) Between school and work: New perspectives on transfer and boundary crossing. (19-39). Amsterdam: Pergamon.

Winsor, D. A. (1996). Writing like an engineer: A rhetorical education. Routledge.

Yeats, D., \& Thompson, I. (2010). Mapping technical and professional communication: A summary and survey of academic locations for programs. Technical Communication Quarterly, 19(3), 225-261.

Recebido em: 27/02/2016

Aceito em: 20/07/2016 


\section{Appendix 1}

\section{List of publications analyzed}

\begin{tabular}{|c|c|c|c|c|c|c|}
\hline \# & Title & Title in English & Author(s) & University & Country & Year \\
\hline 2 & $\begin{array}{l}\text { Creando un } \\
\text { espacio de } \\
\text { investigación } \\
\text { educativa en una } \\
\text { facultad de } \\
\text { ingeniería }\end{array}$ & $\begin{array}{l}\text { Creating an } \\
\text { educational } \\
\text { research space in } \\
\text { an engineering } \\
\text { department }\end{array}$ & $\begin{array}{l}\text { María M. Añino, } \\
\text { Emiliano } \\
\text { Ravera, Diana } \\
\text { M. Waigandt, } \\
\text { Alberto Miyara, } \\
\text { Gustavo Pita, } \\
\text { Marisol Perassi }\end{array}$ & $\begin{array}{l}\text { Universidad } \\
\text { Nacional Entre } \\
\text { Ríos }\end{array}$ & Argentina & 2009 \\
\hline 3 & $\begin{array}{l}\text { Interdisciplinarity: } \\
\text { perspectives for } \\
\text { the design of } \\
\text { Didactic strategies } \\
\text { in engineering }\end{array}$ & $\begin{array}{l}\text { The original case } \\
\text { was written in } \\
\text { English }\end{array}$ & $\begin{array}{l}\text { María M. Añino, } \\
\text { Emiliano } \\
\text { Ravera, Diana } \\
\text { M. Waigandt, } \\
\text { Alberto Miyara, } \\
\text { Gustavo Pita, } \\
\text { Marisol Perassi }\end{array}$ & $\begin{array}{l}\text { Universidad } \\
\text { Nacional Entre } \\
\text { Ríos }\end{array}$ & Argentina & $2010 a$ \\
\hline 4 & $\begin{array}{l}\text { Action Research: } \\
\text { A way to generate } \\
\text { new approaches to } \\
\text { teaching } \\
\text { mathematics in } \\
\text { Bioengineering }\end{array}$ & $\begin{array}{l}\text { The original case } \\
\text { was written in } \\
\text { English }\end{array}$ & $\begin{array}{l}\text { María M. Añino, } \\
\text { Diana M. } \\
\text { Waigandt, } \\
\text { Marisol Perassi, } \\
\text { Gustavo Pita, } \\
\text { Alberto Miyara, } \\
\text { Ernesto } \\
\text { Klimovsky, } \\
\text { Emiliano } \\
\text { Ravera, Hernán } \\
\text { Fernández } \\
\text { Céspedes, } \\
\text { Leandro Escher, } \\
\text { Juan C. } \\
\text { Canavelli }\end{array}$ & $\begin{array}{l}\text { Universidad } \\
\text { Nacional Entre } \\
\text { Ríos }\end{array}$ & Argentina & $2010 b$ \\
\hline 17 & $\begin{array}{l}\text { Academic and } \\
\text { professional genre } \\
\text { Variation across } \\
\text { four disciplines: } \\
\text { Exploring the } \\
\text { pucv-2006 corpus } \\
\text { of Written } \\
\text { Spanish }\end{array}$ & $\begin{array}{l}\text { The original case } \\
\text { was written in } \\
\text { English }\end{array}$ & Giovanni Parodi & $\begin{array}{l}\text { Pontificia } \\
\text { Universidad } \\
\text { Católica de } \\
\text { Valparaíso }\end{array}$ & Chile & $2010 \mathrm{a}$ \\
\hline 18 & $\begin{array}{l}\text { La organización } \\
\text { retórica del } \\
\text { género Manual A } \\
\text { través de cuatro } \\
\text { disciplinas: } \\
\text { ¿cómo se } \\
\text { comunica y } \\
\text { difunde LA } \\
\text { ciencia en } \\
\text { diferentes } \\
\text { Contextos } \\
\text { universitarios? }\end{array}$ & $\begin{array}{l}\text { The rhetoric } \\
\text { organization of the } \\
\text { Manual genre } \\
\text { through four } \\
\text { disciplines: how is } \\
\text { science } \\
\text { communicated and } \\
\text { spread in the } \\
\text { different university } \\
\text { contexts? }\end{array}$ & Giovanni Parodi & $\begin{array}{l}\text { Pontificia } \\
\text { Universidad } \\
\text { Católica de } \\
\text { Valparaíso }\end{array}$ & Chile & $2010 b$ \\
\hline
\end{tabular}




\begin{tabular}{|c|c|c|c|c|c|c|}
\hline 19 & $\begin{array}{l}\text { Multisemiosis and } \\
\text { corpus linguistics: } \\
\text { multisemiotic } \\
\text { artifacts in the texts } \\
\text { of six disciplines in } \\
\text { the academic pucv- } \\
2010 \text { corpus }\end{array}$ & $\begin{array}{l}\text { The original case was } \\
\text { written in English }\end{array}$ & Giovanni Parodi & $\begin{array}{l}\text { Pontificia } \\
\text { Universidad Católica } \\
\text { de Valparaíso }\end{array}$ & Chile & $2010 \mathrm{c}$ \\
\hline 1 & $\begin{array}{l}\text { Los resúmenes } \\
\text { como estrategia } \\
\text { de aprendizaje }\end{array}$ & $\begin{array}{l}\text { Summaries as a learning } \\
\text { strategy }\end{array}$ & $\begin{array}{l}\text { Gladys Stella López } \\
\text { - Ricardo Ramírez }\end{array}$ & $\begin{array}{l}\text { Universidad del } \\
\text { Valle }\end{array}$ & Colombia & 2012 \\
\hline 5 & $\begin{array}{l}\text { Mejorar la } \\
\text { enseñanza y el } \\
\text { aprendizaje de la } \\
\text { Matemática en } \\
\text { Bioingeniería: Un } \\
\text { desafío asumido } \\
\text { desde la } \\
\text { investigación- } \\
\text { acción }\end{array}$ & $\begin{array}{l}\text { Improvement of } \\
\text { Mathematics teaching and } \\
\text { learning in } \\
\text { Bioengineering: a } \\
\text { challenge assumed from } \\
\text { action research }\end{array}$ & $\begin{array}{l}\text { María Magdalena } \\
\text { Añino, Marisol } \\
\text { Perassi, Gabriela } \\
\text { Merino, Emiliano } \\
\text { Ravera, Gustavo Pita, } \\
\text { Alberto Miyara y } \\
\text { Diana Waigandt }\end{array}$ & $\begin{array}{l}\text { Universidad Nacional } \\
\text { Entre Ríos }\end{array}$ & Argentina & 2012 \\
\hline 8 & $\begin{array}{l}\text { Desarrollo de } \\
\text { habilidades de } \\
\text { lectura y escritura } \\
\text { en la trayectoria } \\
\text { académica del } \\
\text { ingeniero: la } \\
\text { experiencia de un } \\
\text { programa } \\
\text { desafiante e } \\
\text { innovador }\end{array}$ & $\begin{array}{l}\text { Reading and writing } \\
\text { abilities development in } \\
\text { the academic process of } \\
\text { the engineer: the } \\
\text { experience of a } \\
\text { challenging and } \\
\text { innovative program }\end{array}$ & $\begin{array}{l}\text { Lucía Natale y Daniela } \\
\text { Stagnaro }\end{array}$ & $\begin{array}{l}\text { Universidad Nacional } \\
\text { de General Sarmiento }\end{array}$ & Argentina & 2012 \\
\hline 14 & $\begin{array}{l}\text { Dificultades de la } \\
\text { escritura de } \\
\text { informes de } \\
\text { investigación } \\
\text { formativa en la } \\
\text { educación superior } \\
\text { en facultades de } \\
\text { Ingeniería }\end{array}$ & $\begin{array}{l}\text { Difficulties in writing } \\
\text { formative research reports } \\
\text { at university level in } \\
\text { engineering }\end{array}$ & Julio Cortés Trujillo & $\begin{array}{l}\text { Universidad de la } \\
\text { Salle }\end{array}$ & Colombia & 2012 \\
\hline 6 & $\begin{array}{l}\text { Early error } \\
\text { detection: an } \\
\text { action-research } \\
\text { experience teaching } \\
\text { vector calculus }\end{array}$ & $\begin{array}{l}\text { The original case was } \\
\text { written in English }\end{array}$ & $\begin{array}{l}\text { María Magdalena } \\
\text { Añinoa, Gabriela } \\
\text { Merinoa, Alberto } \\
\text { Miyaraa, } \\
\text { Marisol Perassia, } \\
\text { Emiliano Raveraa, } \\
\text { Gustavo Pitaa \& Diana } \\
\text { Waigandta }\end{array}$ & $\begin{array}{l}\text { Universidad Nacional } \\
\text { Entre Ríos }\end{array}$ & Argentina & 2013 \\
\hline 7 & $\begin{array}{l}\text { Experiencias de } \\
\text { formación y de } \\
\text { inserción laboral } \\
\text { de ingenieros: las } \\
\text { voces de los } \\
\text { protagonistas desde } \\
\text { una investigación } \\
\text { biográfica }\end{array}$ & $\begin{array}{l}\text { Learning processes and } \\
\text { professional insertion } \\
\text { experiences of engineers: } \\
\text { the voices of the } \\
\text { protagonists from a } \\
\text { biographic research }\end{array}$ & $\begin{array}{l}\text { Paola Verónica } \\
\text { Paoloni } \\
\text { Analía Claudia } \\
\text { Chiecher }\end{array}$ & $\begin{array}{l}\text { Universidad Nacional } \\
\text { de Río Cuarto }\end{array}$ & Argentina & 2013 \\
\hline
\end{tabular}




\begin{tabular}{|c|c|c|c|c|c|c|}
\hline 7 & $\begin{array}{l}\text { Experiencias de } \\
\text { formación y de } \\
\text { inserción laboral de } \\
\text { ingenieros: las } \\
\text { voces de los } \\
\text { protagonistas desde } \\
\text { una investigación } \\
\text { biográfica }\end{array}$ & $\begin{array}{l}\text { Learning processes and } \\
\text { professional insertion } \\
\text { experiences of engineers: } \\
\text { the voices of the } \\
\text { protagonists from a } \\
\text { biographic research }\end{array}$ & $\begin{array}{l}\text { Paola Verónica Paoloni } \\
\text { Analía Claudia } \\
\text { Chiecher }\end{array}$ & $\begin{array}{l}\text { Universidad Nacional } \\
\text { de Río Cuarto }\end{array}$ & Argentina & 2013 \\
\hline 9 & $\begin{array}{l}\text { Desarrollo de } \\
\text { competencias } \\
\text { comunicativas en la } \\
\text { formación del } \\
\text { ingeniero: una } \\
\text { propuesta } \\
\text { interdisciplinaria }\end{array}$ & $\begin{array}{l}\text { Development of } \\
\text { communicative } \\
\text { competences in the } \\
\text { engineer learning process: } \\
\text { an interdisciplinary } \\
\text { proposal }\end{array}$ & $\begin{array}{l}\text { Daniela Stagnaro, } \\
\text { Franco Chiodi y } \\
\text { Paula Miguez }\end{array}$ & $\begin{array}{l}\text { Universidad Nacional } \\
\text { de General Sarmiento }\end{array}$ & Argentina & 2013 \\
\hline 21 & $\begin{array}{l}\text { Géneros } \\
\text { profesionales en la } \\
\text { formación del } \\
\text { ingeniero }\end{array}$ & $\begin{array}{l}\text { Professional genres in the } \\
\text { engineer learning process }\end{array}$ & $\begin{array}{l}\text { Stagnaro, Daniela, } \\
\text { Jauré, María Florencia }\end{array}$ & $\begin{array}{l}\text { Universidad Nacional } \\
\text { de General Sarmiento }\end{array}$ & Argentina & 2013 \\
\hline 10 & $\begin{array}{l}\text { Integración de la } \\
\text { lectura y la } \\
\text { escritura en el } \\
\text { curso de } \\
\text { laboratorio de } \\
\text { dispositivos } \\
\text { electrónicos de } \\
\text { ingeniería } \\
\text { electrónica }\end{array}$ & $\begin{array}{l}\text { Integration of reading and } \\
\text { writing in the laboratory } \\
\text { course of electronic } \\
\text { devices in Electronic } \\
\text { Engineering }\end{array}$ & $\begin{array}{l}\text { Duvan Fernando } \\
\text { García C, Nathaly } \\
\text { Nieto R y Alexander } \\
\text { Vera T }\end{array}$ & Universidad del Valle & Colombia & 2014 \\
\hline 11 & $\begin{array}{l}\text { El cambio de } \\
\text { concepción sobre } \\
\text { escritura del } \\
\text { asesorado tras la } \\
\text { revisión entre } \\
\text { pares: una } \\
\text { experiencia del } \\
\text { grupo de apoyo } \\
\text { para la lectura y } \\
\text { escritura en la } \\
\text { facultad de } \\
\text { ingeniería }\end{array}$ & $\begin{array}{l}\text { The change in the writing } \\
\text { conception of the advised } \\
\text { after peer revision: an } \\
\text { experience of the support } \\
\text { group for reading and } \\
\text { writing in the engineering } \\
\text { faculty }\end{array}$ & $\begin{array}{l}\text { Diego Fernando } \\
\text { Gómez León }\end{array}$ & Universidad del Valle & Colombia & 2014 \\
\hline 12 & $\begin{array}{l}\text { Incidencia del } \\
\text { grupo de apoyo } \\
\text { para la lectura y } \\
\text { escritura en la } \\
\text { construcción de } \\
\text { conocimiento de } \\
\text { estudiantes de } \\
\text { ingeniería }\end{array}$ & $\begin{array}{l}\text { The influence of the } \\
\text { support group for reading } \\
\text { and writing in the } \\
\text { knowledge construction } \\
\text { for engineering students }\end{array}$ & $\begin{array}{l}\text { Carol Sánchez } \\
\text { Rodríguez y Juan } \\
\text { Camilo Valderrama } \\
\text { Quiñones }\end{array}$ & Universidad del Valle & Colombia & 2014 \\
\hline 13 & $\begin{array}{l}\text { Escribir para } \\
\text { aprender y } \\
\text { comunicar en la } \\
\text { asignatura } \\
\text { Procesos de } \\
\text { Ingenieria de } \\
\text { Software. Trabajo } \\
\text { colaborativo entre } \\
\text { docentes de lengua } \\
\text { y docentes de las } \\
\text { disciplinas }\end{array}$ & $\begin{array}{l}\text { Writing as a means of } \\
\text { learning and } \\
\text { communication in the } \\
\text { Engineering Software } \\
\text { Processes course. } \\
\text { Collaborative work } \\
\text { between language teachers } \\
\text { and those of other } \\
\text { disciplines }\end{array}$ & $\begin{array}{l}\text { Karen Shirley López } \\
\text { Gil1 y Juan Carlos } \\
\text { Martínez Arias }\end{array}$ & $\begin{array}{l}\text { Pontificia } \\
\text { Universidad } \\
\text { Javeriana de Cali }\end{array}$ & Colombia & 2014 \\
\hline
\end{tabular}




\begin{tabular}{|c|c|c|c|c|c|c|}
\hline 15 & $\begin{array}{l}\text { Elaboración de } \\
\text { resúmenes, una } \\
\text { estrategia de } \\
\text { estudio en } \\
\text { ingeniería }\end{array}$ & $\begin{array}{l}\text { Writing summaries, a } \\
\text { learning strategy in } \\
\text { engineering }\end{array}$ & $\begin{array}{l}\text { Ricardo Ramírez } \\
\text { Giraldo y Gladys Stella } \\
\text { López Jiménez }\end{array}$ & Universidad del Valle & Colombia & 2014 \\
\hline 16 & $\begin{array}{l}\text { Orientación y } \\
\text { evaluación de la } \\
\text { escritura en } \\
\text { asignaturas } \\
\text { disciplinares. } \\
\text { Experiencia de } \\
\text { trabajo } \\
\text { colaborativo } \\
\text { docente }\end{array}$ & $\begin{array}{l}\text { Orientation and evaluation } \\
\text { of writing in disciplinary } \\
\text { subjects. A teacher } \\
\text { collaborative work } \\
\text { experience }\end{array}$ & $\begin{array}{l}\text { Karen Shirley López } \\
\text { Gil y Violeta Molina } \\
\text { Natera }\end{array}$ & $\begin{array}{l}\text { Pontificia } \\
\text { Universidad } \\
\text { Javeriana de Cali }\end{array}$ & Colombia & 2015 \\
\hline 20 & $\begin{array}{l}\text { Alfabetización } \\
\text { profesional durante } \\
\text { la carrera } \\
\text { universitaria: entre } \\
\text { la universidad y la } \\
\text { empresa }\end{array}$ & $\begin{array}{l}\text { Professional literacy } \\
\text { during the university } \\
\text { career: between the } \\
\text { university and the } \\
\text { enterprise }\end{array}$ & $\begin{array}{l}\text { Lucía Natale } \\
\text { Daniela Stagnaro }\end{array}$ & $\begin{array}{l}\text { Universidad Nacional } \\
\text { de General Sarmiento }\end{array}$ & Argentina & 2015 \\
\hline 22 & $\begin{array}{l}\text { Géneros y } \\
\text { formación } \\
\text { ingenieril: de la } \\
\text { universidad a la } \\
\text { industria }\end{array}$ & $\begin{array}{l}\text { Genres and engineering } \\
\text { education: from university } \\
\text { to the industry }\end{array}$ & Lucía Natale & $\begin{array}{l}\text { Universidad Nacional } \\
\text { de General Sarmiento }\end{array}$ & Argentina & 2015 \\
\hline
\end{tabular}

